\title{
The Experiences of Nikkei- Australian Soldiers During World War II
}
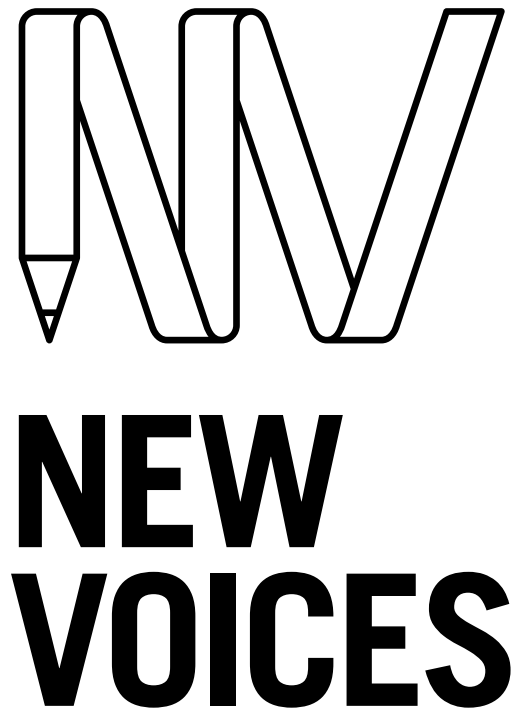

\section{SHANNON WHILEY}

The University of Queensland

\section{ABSTRACT}

This paper is a biographical case study that explores the distinct experiences of three Australian-born Japanese (hereafter, Nikkei-Australians) who volunteered for Australian military service during World War II: Mario Takasuka, Joseph Suzuki and Winston Ide. It examines the social and political context in which these soldiers lived, concluding that they faced a disconnect between the way they were viewed by the government, their local communities and themselves. Notions of identity and nationalism are also explored in the context of World War II and the White Australia Policy, and are compared with the experiences of non-European soldiers in Australia and Nikkei soldiers abroad. The paper also highlights the ambiguous position of Nikkei-Australian soldiers with respect to military enlistment. At the time, legislation allowed for Nikkei-Australians to be variously classified as loyal citizens capable of enlistment, as not sufficiently 'Australian' for duty, or as enemy aliens, depending upon how it was applied in each case. Because there was no uniform approach within the government for applying these laws, the experiences of Nikkei-Australians vastly differed, as illustrated by the stories of the individuals profiled in this study. These stories are important as they add to the growing body of knowledge around non-white Australians who served in World War II, and remind us of how the pro-white, anti-Japanese atmosphere within Australia at the time affected those within the community who did not fit the mould of the White Australian ideal.

\section{KEYWORDS}

Australia; diaspora; history; Japanese Australian; Japaneseness; law; Nikkei; politics; Second Australian Imperial Force; social and cultural identity; soldiers; state; stereotypes; White Australia Policy; World War II

\section{JAPANFOUNDATION 8} BRINGING JAPAN TO YOU

To link to this article: https://doi.org/10.21159/nvjs.10.01

\section{ISSN 2205-3166}

New Voices in Japanese Studies is an interdisciplinary, peer-reviewed journal showcasing the work of emerging scholars from Australia and New Zealand with research interests in Japan.

All articles can be downloaded free at newvoices.org.au

(c) The Japan Foundation, Sydney and Shannon Whiley, 2018

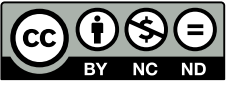

This work is licensed under a Creative Commons Attribution-NonCommercialNoDerivatives 4.0 International License. 


\section{INTRODUCTION}

This paper explores the experiences of a small number of Australians of Japanese descent who served in the Australian military during World War II. It examines their stories in the context of an anti-Asian and Japan-fearing Australia in the early to mid-twentieth century. The wartime experiences of Japanese migrants and their Australian-born descendants (hereafter referred to as Nikkei-Australians) were influenced greatly by the Immigration Restriction Act 1901 and other pieces of legislation that made up the White Australia Policy. ${ }^{1}$ Nikkei-Australians faced great hardships as a result of these policies, which contributed to anti-Japanese sentiment and culminated in the internment of many from 1941. It was in this context that the three NikkeiAustralians profiled in this study volunteered for military service in the Second Australian Imperial Force (AIF). ${ }^{2}$

Research into the histories and experiences of Nikkei-Australians is a developing area with great potential for revealing important stories from non-white Australian perspectives. The experiences of Nikkei-Australians during World War II can be shown to have differed greatly from those of white Australians. Within this context, this article focuses specifically on the experiences of Nikkei who served in the military. Officially, Nikkei-Australians were prohibited from military service, although several were still able to enlist (Nagata 1996, 105). As a result, those who did enlist found themselves in an ambiguous position, fighting for a country that interned their families and classified them as enemy aliens. While scholars have investigated the stories of Nikkei-Australians as a broader population, the stories of Nikkei-Australian soldiers have yet to be explored or examined through the specific lens of their shared military experiences. This is the gap that my paper seeks to address.

Using archival case studies of three Nikkei-Australian soldiers who served in World War II, I will examine how individual variations in the nature of their Japanese heritage influenced their treatment during the war, from 1939 to 1945 . The paper will also delve into questions surrounding the identity of these soldiers, focusing on the tensions between three different images of Nikkei-Australians: 1) how they were seen bureaucratically and legislatively; 2) how they were seen by their local communities and peers; and 3) how they saw themselves. It will show that despite being classified as enemy aliens by the state, Nikkei-Australians were generally accepted by their peers and did not conform to the stereotypes of Japanese people that prevailed within the government and the greater community. As documentation and research relating to Nikkei-Australian soldiers is notably scarce, the paper will also draw from a range of secondary sources on the wartime experiences of non-Australian Nikkei soldiers and Australian soldiers from non-Nikkei racial minorities. These sources focus on the more-widely researched North-American Nikkei soldiers, as well as Chinese-Australian soldiers and

1 Several Japanese terms will be used throughout this paper. 'Nikkei' (日系), meaning 'of Japanese descent', refers to the Japanese diaspora. 'Issei' (一世) and 'Nisei' (二世) refer to the first generation (born in Japan) and second generation (born outside Japan to Issei parents) of the Japanese diaspora respectively. 'NikkeiAustralian' is a modern term referring to cultural heritage as opposed to nationality.

The White Australia Policy was made up of the Immigration Restriction Act 1901, the Naturalisation Act 1903, the Alien Registration Act 1920 and several smaller pieces of legislation.

2 The Second Australian Imperial Force is the name given to the main force of the Australian military that served in World War II. 
Indigenous Australian soldiers. Utilising these stories offers a way of bridging gaps in knowledge regarding the Nikkei-Australian community.

The study collates important examples of non-white Australian experiences during the era of the White Australia Policy. Research of this nature is vital to ensuring commemoration for Nikkei-Australian and other non-white Australian soldiers, given the complexities of their involvement in the war due to their heritage and the political climate of the time. As Australian war historian Jeannine Baker has stated regarding the commemoration of nonwhite Australian soldiers, a universally white Australia "was never true and it's important to recognise that" (Baker et al. 2017). This paper contributes to the growing body of literature commemorating those non-European Australians who served in the military under the White Australia Policy.

\section{METHODOLOGY}

In this paper I utilise archival documents found mainly in the National Archives of Australia (NAA) to examine how race, and mainstream attitudes towards race, shaped the treatment of Nikkei-Australians who served in the Second Australian Imperial Force (AIF) during World War II. The study builds on the research of Nikkei-Australian diaspora scholars such as Yuriko Nagata, Pam Oliver and D. C. S. Sissons. Their identification of several individuals who were members of the Japanese diaspora and also served in the Australian military during World War II has been invaluable to this study. There is no official record of Nikkei-Australian soldiers who served in World War II because Nikkei-Australians were prohibited from enlisting. NikkeiAustralians who did serve in the military were only able to register when enlistment centres were unaware of the enlistee's heritage or regulations regarding race, and therefore information on race was never recorded at the time of enlistment. ${ }^{3}$ Race was generally only noted on attestation papers if it was the reason for discharge (Australian War Memorial [AWM] n.d.[a]). The list of cases collected here therefore represents only a small cross-section of the most diverse and well-documented experiences.

The study focuses on three Nikkei-Australian soldiers and their families, and builds on existing research by analysing the soldiers' respective military experiences with reference to archival information I have located. These soldiers are Mario Takasuka [1910-1999], Joseph Suzuki [b. 1922] and Winston Ide [1914-1944]. ${ }^{4}$ These men are notable because their varying backgrounds and experiences, when examined together, highlight the different social and legal attitudes toward Nikkei-Australians during World War II. They are also distinguished by the relative availability of their historical records. A total of 17 Nikkei soldiers who served in the Australian military have been identified in prior research; however, a comprehensive review of each of these individuals is outside the scope of this study. Known Nikkei-Australian soldiers who served World War II are instead listed in a table in the Appendix. 


\section{HISTORICAL CONTEXT: EARLY TO MID-TWENTIETH CENTURY AUSTRALIA}

Australian policy towards Japan in the early to mid-twentieth century was influenced by a combination of racial attitudes and a perceived exposed position as a European colony in Asia (Anderson 2006, 148). While the severity of Japan's threat to Australian sovereignty and the specifically anti-Japanese sentiment of the time has sometimes been overstated, it is true that politicians and the media did have reservations about Japan long before Japan entered World War II and became an official enemy of Australia (Sissons 1956, 2). Japan's victories in its various wars with China [1895] and Russia [1905] had shown its potential as a strong maritime power, and Japan used this to push for parity with the Western powers-something that the Australian government was staunchly against (Stead 1904, 84-85). Moreover, the notion that Japanese workers could migrate in large numbers and undercut European workers had caused concern within the government and the Australian labour union movement since the gold rush of the 1850s (Haid 2011, 39-40). These fears of a rising Japan directly contributed to the introduction of policies such as the Immigration Restriction Act in 1901 and the establishment of Japanese language classes at the military college of Duntroon in 1917, despite Japan being a nominal ally at the time (Stead 1904; Meaney 2009, 156). During World War II the fear of a Japanese invasion did not seem unfounded, especially between 1942 and 1943, with skirmishes in and around Australian territories during that period referred to by then Prime Minister John Curtin as the "Battle for Australia" (NAA 2017). ${ }^{5}$ Although evidence later emerged that Japan had no real plans for a full-scale invasion of Australia, the atmosphere at the time was increasingly anti-Japanese (Bullard 2006, 21-22). As will be shown below, these policies and fears directly influenced Nikkei-Australian experiences.

\section{IMMIGRATION, NATURALISATION AND CITIZENSHIP POLICIES BETWEEN 1901 AND 1945}

The immigration policies of early twentieth-century Australia were known for favouring white British immigrants. Consequently, the Japanese community in Australia was small and faced discrimination on several fronts (Oliver 2002, 277). The acts that combined to form the White Australia Policy (see footnote 2) were the most significant pieces of legislation affecting the Japanese community in Australia between 1901 and 1945. The Immigration Restriction Act 1901 explicitly excluded Asians and other non-Europeans from entry into Australia. Anti-Chinese sentiment had been building since the gold rush of the 1850s and played an important role in limiting Asian immigration; the smaller Japanese community was oftentimes conflated with the Chinese or simply labelled as 'Asian' (Haid 2011, 43). Nikkei-Australian Hannah Suzuki [b. 1920] stated that during the war she was often mistaken in the community for being Chinese (Nagata 1996, 105). In this way, many of the difficulties faced by Nikkei-Australians were not unique to the Japanese community.

5 One important battle early on in the conflict between Australia and Japan was the Fall of Singapore. This battle was fought between British Allied Forces and Japan at the British Naval Base in Singapore in February 1942. After a decisive victory by the Japanese, 130,000 people were taken as prisoners of war. Japanese war planes bombed Darwin four days after the British surrendered at Singapore. These events were notable as major victories by Japan against Australian troops, and were important as they were seen as a progression towards an invasion of Australia by Japan (Rowland 2017). 
Although anti-immigration legislation does not name the Nikkei-Australian community, several researchers have asserted that it was targeted specifically. Alfred Stead (1904), a researcher in Japanese studies who vehemently opposed the Immigration Restriction Act, argued at the time that the act was primarily introduced to prevent an influx of Japanese migrants (95). Haid (2011) reasons that while the government made little effort to conceal its contempt for Japanese immigrants, an ambiguous restriction method was chosen for diplomatic reasons (51-52). These assertions are supported by statements made by those in power at the time, including Attorney-General Alfred Deakin, who stated: "I contend that the Japanese require to be absolutely excluded [from immigrating to Australia] because of their high abilities [...]. [They] are the most dangerous because they most nearly approach us, and would therefore be our most formidable competitors" (cited in Stead 1904, 95). In practice, this sentiment led to increasingly discriminatory treatment of Nikkei-Australians compared with their Chinese and other Asian-Australian counterparts, and importantly influenced the decision to intern Nikkei-Australians as enemy aliens from 1941 to 1947 (Nagata 2008, 112). As a result of these policies, the Nikkei-Australian community at the start of World War II consisted of those who had arrived before 1901, a small number of people who were able to obtain an exemption and had arrived later, and their descendants. In 1941, this population was estimated at 1,139-around 821 of whom were deported after the war (Haid 2011, 3, 8). ${ }^{6}$

This discriminatory treatment is most clearly reflected in the citizenship rights of Japanese immigrants and their Australian-born descendants, which influenced government and military policy towards Nikkei during World War II. Prior to 1901, it had been possible for Japanese nationals to become naturalised Australian [British] citizens; however, the enactment of the White Australia Policy through the Immigration Restriction Act 1901 effectively annulled this right until 1958, when the act was repealed (Oliver 2008, 125-28, 134). ${ }^{7}$ During the period that the White Australia Policy was in effect, access to citizenship rights became complex for Nikkei and other racial minorities, and factors such as race, country of birth and paternal nationality were used to determine eligibility for citizenship (Beaumont et al. 2008, 5).

The Naturalisation Act 1903 also had a significant impact on citizenship rights. The act stated that only Australian residents who were not "aboriginal native[s] of Asia, Africa or the Islands of the Pacific" were eligible to apply for a certificate of naturalisation. In 1923, one individual, Jiro Muramats, challenged this in the High Court of Australia as he was not an indigenous Japanese (Ainu); however, the court eventually ruled that the word "native" referred to the native race in Japan "from a European perspective" (Haid 2011, 69). ${ }^{8}$ According to Oliver, the wording of this legislation was intentionally left vague and undefined for those who wished to prevent non-whites from claiming citizenship (Oliver 2008, 135). 
Conflicting legislation similarly complicated the citizenship status of Australian-born second-generation Nikkei, known as 'Nisei'. Section 6 of the Commonwealth Nationality Act 1920-30 automatically conferred citizenship on anyone born in Australia, meaning that Nisei should have been considered natural-born Australian [British] citizens under this law. However, according to the Aliens Registration Act 1920, the wife and children of an alien (meaning 'non-citizen' in theory, but in practice meaning 'non-European') could also be classified as aliens, meaning that second-generation immigrants such as Nisei were not necessarily guaranteed citizenship (Nagata 1996, 56-59). These unclear legal definitions forced Nikkei-Australians to exist in a state of ambiguity, especially in wartime. Without the Aliens Registration Act, Nisei would have been classified as Australians rather than enemy aliens.

Underpinning these laws were the prevailing racial theories of the time. The two most significant were those of Charles Pearson, who developed a racial hierarchy theory that influenced Australia's immigration policy, and W. H. Barnwell, whose report on Japanese characteristics and theory of Japanese espionage was used to mark Nikkei-Australians as potential spies as early as the 1920s (Oliver 2002, 274-75; Oliver 2008, 139). Pearson, a Britishborn historian and politician based in Australia, argued that "black and yellow races" (in particular, the Chinese), would grow in population and influence to eventually "supersede" Europeans (Pearson 1893, 32). These theories influenced future Australian Prime Ministers Edmund Barton and Alfred Deakin, the former quoting Pearson's research when campaigning for the Immigration Restriction Act in 1901 (Haid 2011, 48; Pearson 1893, 29). Barnwell's theory, which built on a combination of Pearson's work and information from Australia's security forces, outlined what he deemed to be intrinsic characteristics of the Japanese: secretiveness; untrustworthiness; belonging to the "emperor cult"; and having expertise in espionage tactics (Oliver 2002, 275). Exceptions could be made in cases where an individual did not speak Japanese, was born in Australia, or had a white parent (Oliver 2002, 274-75). However, many officials at the time held firmly to the belief that Nikkei-Australians could never become Australian in their outlook, and that any attempt to do so should be treated with suspicion (Oliver 2002, 287). Barnwell's espionage theory eventually contributed to justifying the internment camps set up in Australia from 1941 to 1947 (Oliver 2002, 274-75). ${ }^{9}$

\section{INTERNMENT POLICY}

After the outbreak of World War II, immigrants from enemy nations and their Australian-born children living in Australia were classified as enemy aliens and interned in camps to minimise their perceived threat to the public and to national security (Beaumont et al. 2008, 67). Those interned included

result of Western Australia retracting his right to vote (Sissons 1986). In 1923, his name was reinstated on the electoral roll. However, his petition to regain citizenship was unsuccessful, which led him to take his case to the High Court. Muramats was interned as a Japanese during World War II and died in internment (Haid 2011, 69). Note that Japanese names reproduced in this paper follow spellings used in official Australian records where possible, or otherwise follow the dominant spellings used in extant literature on Nikkei-Australians. 
German, Italian and Japanese civilians, and in some cases their descendants (Haid 2011, 25). However, while European-Australians were only selectively interned based on alleged security risk and connection to fascist ideologies, it was decreed that all Japanese persons over 16 years of age should be taken into custody (Rando 2005, 27-28; Hayman 1980, 31)..$^{10}$ The legal definition of who was Japanese was unclear, so in practice the internment included Australianborn citizens with Japanese heritage, young children and even Australian spouses of Japanese (Nagata 1996, 51-56). ${ }^{11}$ As Asians, Nikkei-Australians were more easily visually identifiable than those with European heritage, and were thought to pose a greater threat to Australia than non-Asian enemy nationals (Nagata 2008, 112). According to Nagata, the Australian government took the approach of a comprehensive Nikkei internment for four reasons:

...because authorities thought that there were no Japanese associations that might easily indicate the extent of an individual's attachment to his homeland; that the Japanese were not absorbed into Australian society; that they were fanatical and devoted to their homeland and therefore capable of sabotage; and that Japanese men, if left free, would be the target of anti-Japanese public demonstrations.

(Nagata 2008, 112)

In short, anti-Japanese propaganda and the racial policies of the time heavily influenced the decision to intern Nikkei-Australians indiscriminately. Of the three Nikkei-Australian soldiers profiled in this study, one (Joseph Suzuki) was interned, and all had family members who were interned. This internment policy had lasting effects on the Nikkei community in Australia. After the war, the government used this same policy framework as a justification for deporting the majority of Nikkei-Australians, with the exception of those who were Australian-born or those who had Australian-born family members (Nagata 1996, 193). This is further evidence not only of anti-Japanese sentiment within the Australian government at the time, but also of how the government did not consider Nikkei-Australians to be 'Australian'. Although some Nikkei returned to Australia in the 1950s, the post-war Nikkei-Australian community has very few ties to the pre-war community (Nagata 1996).

\section{MILITARY POLICY}

Even prior to World War II, Nikkei-Australians were prohibited from enlisting in the military on racial grounds. Australian Military Regulation No. 177 of the Defence Act 1909 specified that "those who are not substantially of European origin or descent" were to be excluded from service, determined at the discretion of an appointed medical professional (Nagata 1996, 105). As a result, Nikkei-Australians who did serve in the military while this act was in force were only able to enlist by hiding their ancestry from enlistment staff. In cases where the heritage of these individuals was discovered after enlistment, some were able to retain their positions due to intervention and advocacy by their superiors and peers, as will be discussed below (Oliver 2002, 285-88). 
Bureaucratic distrust of Nikkei-Australians meant that they were not considered for military armed service roles, or even translation and interpretation roles-although there were Nikkei-Australians with knowledge of both English and Japanese who may have been suitable for and useful in such positions (Oliver and NAA 2004, 20,126). This was due to the pervasive notion at the time that Nikkei in Australia were spies, and were loyal only to the Japanese emperor (Saunders 1994, 331; Oliver 2002, 275). Instead, World War II Allied Forces employed North-American Nisei and Japanese-speaking Australians of European origin as translators during World War II (Queensland Government 2014). The Allied Translator and Interpreter Service (ATIS, also known as the Allied Translator and Interpreter Section) was a joint Australian/American World War II intelligence agency responsible for translation and intelligence gathering, including interviewing Japanese prisoners of war (POWs) sent to Australia. It is unclear why Nikkei-Americans were considered when local Nikkei-Australians were not, although it is possible that Australian military officials were not able to change American personnel choices even if they disagreed with them.

Importantly, it was not only the Japanese diaspora, including individuals of mixed Japanese heritage, who were prohibited from enlisting in the Australian military during World War II. As the Defence Act 1909 excluded from enlistment any persons not of substantial European heritage, this also extended to racial minorities such as Aboriginal and Torres Strait Islanders and Chinese-Australians. However, despite the legal barrier, a great number of non-European Australians did enlist, including over 1,300 Indigenous Australians and 200 Chinese-Australians (AWM n.d.[a]). ${ }^{12}$ By 1942, the AIF became more desperate for recruits, and rules were informally relaxed to allow enemy aliens who were not perceived as a security threat to volunteer for service. However, this policy shift still excluded all Japanese, even while many Chinese-Australians were permitted to enlist (Clyne et al. 2015, 32; Beaumont et al. 2008, 5-6). Amendments to the Defence Act in 1943 also allowed for a more relaxed approach when it came to recruiting Aboriginal and Torres Strait Islander applicants, primarily due to the need for more men (Londey 2015). A similar relaxation of rules for Nikkei-Australians was generally not applied, largely because of Japan's status as an enemy of Australia. Thus, it was not simply the fact that Nikkei-Australians were non-European, nor that they were enemy aliens, but rather a combination of both that prohibited them from serving.

Historically, the experiences of Chinese-Australian and Indigenous Australian soldiers, like those of Nikkei-Australians, have largely gone uncelebrated (Baker et al. 2017). Recently, however, the centenary of World War I has helped to provide a platform for the stories of Chinese-Australian soldiers such as Billy Sing and Caleb Shang, and Indigenous Australian soldiers such as Reginald Saunders, to be shared in the mass media (Yu 2017; Moremon n.d.). This has facilitated an awareness that non-European Australians also contributed to the war effort during the era of White Australia. The monument to Indigenous soldiers in Sydney's Hyde Park, which was commissioned by the City of Sydney and unveiled in 2015, is one example of a public act of 
acknowledgement following a call for greater consciousness of non-white soldiers (Kembrey 2015). ${ }^{13}$ However, the smaller size of the Japanese community, fewer known surviving soldiers, and fewer academic studies has meant that Nikkei-Australian soldiers have not received the same attention.

Overall, the Australian military took a very hard-line approach to keeping people of Japanese descent outside of its ranks. Multiple factors led to the small number of Nikkei-Australians serving in the AIF, and racial ideas within Australia questioned the trustworthiness of anyone with Japanese blood. Together, these elements made it very difficult for Nikkei-Australians to successfully enlist in the AIF, and to remain soldiers after Japan entered the war. This is illustrated in the biographical accounts of the three NikkeiAustralian soldiers presented below.

\section{BIOGRAPHIES OF NIKKEI-AUSTRALIAN SOLDIERS}

\section{Mario Takasuka}

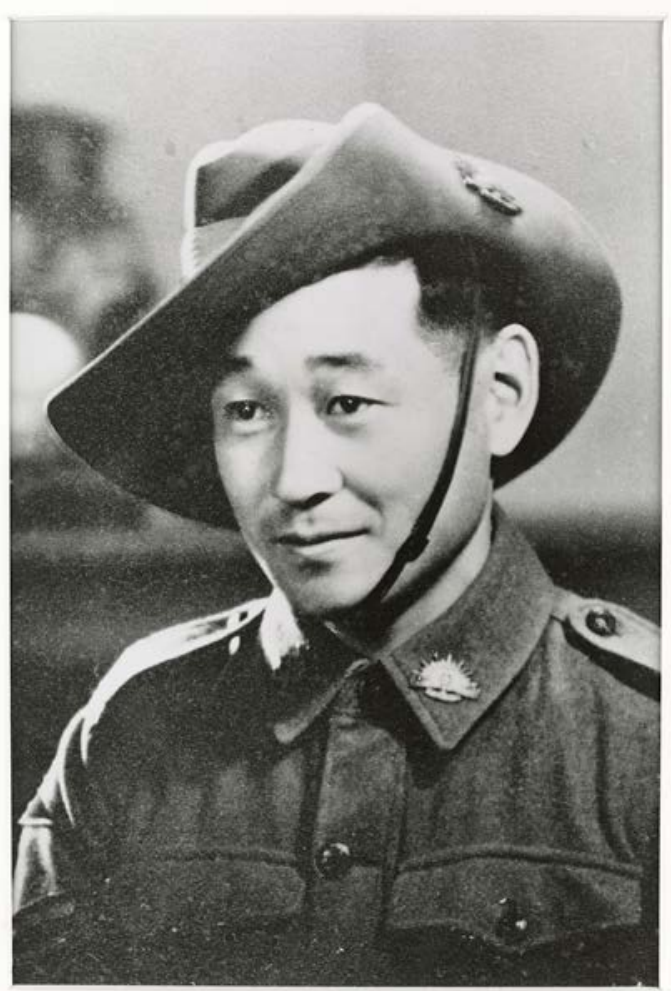

Figure 1: "Mario [Takasuka] on leave in Cairo, 1941" (Source: Building a Country Archive, Pictures Collection, State Library of Victoria. Accession number: H92.400/96)

Born in Swan Hill in 1910, Mario Takasuka was a Nisei and the youngest of three children. His parents Jo and Ichiko Takasuka and older brother Sho arrived in Australia on March 13, 1905. Unlike typical Japanese immigrants of the time, the Takasuka family were university-educated and were of the samurai class. They were early pioneers of Australian-Japanese trade relations through the importation of Japanese art, and were also responsible for the growth of the rice industry in Australia due to Jo's experiments with rice 
cultivation in Australian soil (Sissons 1980). The Takasuka family were able to obtain entry into Australia despite the Immigration Restriction Act and were permitted to remain in Australia for an extended period because of their important cultivation research (Oliver 2008, 131). Before the war, Mario worked as an orchardist in Fosterville with his father. ${ }^{14}$

In 1940, Mario volunteered locally to join the AIF. After being rejected twice, he was eventually accepted by enlisting in Melbourne, where his background was unknown and the recruiting officer was also unaware of the military regulations regarding race (Hayman 1980). Mario initially served in Crete and Alexandria in the 2/3 Light Anti-Aircraft regiment (Sissons 1980). When Japan entered the war at the end of 1941, military authorities made strong efforts to remove him. An enquiry was ordered when "the presence of a full-blooded Japanese in the Australian army came to the attention of the Minister" (Sissons 1980). Mario was a well-regarded member of his unit, and his commanding officer successfully argued for his continued deployment, stating: "His record as a soldier both in and out of action has been exemplary and in consideration of his outstanding service in Crete, I selected him for promotion as a bombardier. He is most popular with the men in his [battalion] and the recent declaration of war against Japan has in no way affected his popularity or his ambition to serve" (NAA: B883, VX37123). Mario remained with his unit and went on to serve in Palestine (where he received a written commendation from his general for his efforts in a train crash rescue), and in New Guinea, after being promoted to gun sergeant (Hayman 1980; Sissons 1980; Lewis 2012). Mario returned from the war in 1945 and continued to live in Australia until his death in 1999, aged 89 (Bryant 1989, 6; 2nd/3rd Australian Light Anti-Aircraft Regiment Association 2011; State Library of South Australia 2017).

\section{Winston Ide}

Winston Phillip James Ide was born in 1914 to a Japanese silk importer named Hideichiro (Henry) Ide and his Australian wife Clara (Growden 2012). Nicknamed 'Blow' after a childhood habit, Winston was a member of the 1939 Australian National Rugby team, the Wallabies (Lane 2011). While on his way to tour with the Wallabies in England in September 1939, war broke out. Ide enlisted in the AIF on 1 July 1940 at Kelvin Grove, Queensland, inspired by what he had seen in Europe (NAA: B883, QX13648; Lane 2011; AWM 2013). He joined the field regiment and in 1941 was sent to Singapore as a bombardier in Unit 2/10 (AWM 2013).

In February 1942, Singapore fell to the Japanese. Ide was among those taken prisoner at Changi in the surrender. On May 14, he was dispatched to Burma with 'A Force', and for two years worked as a POW for the Japanese, building the Thai-Burma Railway. ${ }^{15}$ His family held grave fears that he would be singled out as a traitor. However, "despite his Japanese ancestry, Ide was treated no differently to his fellow prisoners. Like all Australian prisoners in Burma and 
Thailand he was ravaged by disease, malnutrition and overwork" (Blackburn 2012, 213; see also AWM 2013). It is unknown whether the Japanese military became aware of his origins. In 1944, Ide and over 1,300 other POWs boarded a Japanese cargo ship named the Rakuyo Maru to be transported to Japan (Blackburn 2012, 214). On September 12 of that year, under the impression they were intercepting cargo, the American submarine Sealion torpedoed the Rakuyo Maru, along with the Kachidoki Maru, another Japanese cargo ship which was carrying British POWs (Lane 2011; San Francisco Maritime National Park Association 2007).

Ide is thought to have drowned assisting fellow soldiers who could not swim. Despite calls from comrades to climb aboard a life raft, Ide apparently stayed back to help fellow POWs (Growden 2012). He was last seen floating in the water, calling out that he was uninjured but that "some of the boys had been hurt... [so] he would stick by them for a while" (AWM 2013). His body was sadly never recovered; however, he was commemorated at Labuan Memorial Cemetery in Malaysia, off the coast of Borneo, as one of the 1,559 POWs who perished in the dual sinking (NAA: B883, QX13648; AWM 2013). He was 29 years old.

Kevin Blackburn (author of Sportsmen of Changi) has pointed out that Ide "died without knowing that government officials of his country did not have the confidence in him and his family that his rugby union mates had" (Growden 2012). In fact, the Australian government had been investigating Ide for possible sympathies toward Japan due to his ancestry. He also died apparently unaware that his father had been interned at Hay (Growden 2012). Before departing for the war, he had announced his engagement to Heather Jean Reynolds; however, they were never married and he has no known descendants (Blackburn 2012, 32). To honour his memory, in 1947 the Blow Ide Cup was established, and was played between Sydney rugby teams involving Ide's friends and colleagues (Blackburn 2012, 216). In 2013, there was also a Last Post Ceremony held at the Australian War Memorial in his honour. A memorial written by his friends reads: "Blow Ide died as he had always played-for his team" (Blackburn 2012, 216).

According to Blackburn, Ide is seen as a rugby role model in modern-day Japan, partly as a result of promotion by Japan's Rugby League Association (Blackburn 2012, 253). His story inspired the Japanese novel "The Fatal Full-Time” (死に至るノーサイド), a fictionalised account of Ide’s life written by Tsutomu Kaniya (蟹谷 勉), which was adapted into a TV documentary entitled “Did You Hear The Full-Time Whistle?” (君はノーサイドの笛を聞いた か) in 2010 (Kaniya 1993; “Kimi wa nōsaido" 2009). He also features in the book Sportsmen of Changi (Blackburn 2012), which examines the lives of Australian sportsmen who became POWs. Ide is believed to be one of three Nikkei soldiers from the Allied Forces to have become a Japanese POW; the other two were Nikkei-Americans Frank Fujita and Richard Sakakida (Fujita 1993; Densho 2017). Due to his rugby connections, Ide is probably the most widely known Nikkei-Australian to have fought in World War II. 


\section{Joseph Suzuki}

Joseph was born Ichero Shibuya in Mikage, in the Japanese city of Kobe on February 28, 1922, and migrated to Australia with his Australian mother Ada May Suzuki (née Quinn, also known as Ada May Shibuya) and sister Hannah just after his birth. ${ }^{16}$ Joseph's father was a Japanese ship captain named Harohiko Shibuya; the family name of Joseph and his siblings became Suzuki after his mother's second marriage to Sakuhei Suzuki (Oliver 2002). Joseph was an apprentice surveyor at the time of his enlistment. On June 19, 1940 he registered for service in the AIF in Sydney, falsely listing his birthplace as Geelong and his name as Joseph Suzuki (his first name was still legally Ichero), as well as raising his age to twenty-two (NAA: B883, NX32903). On his enlistment experience, he is quoted as saying, "I was only seventeen. I knew that I was entitled to serve Australia" (Nagata 1996, 106). Joseph served in the 2/1 Survey Regiment in Australia until February 21, 1941, when his identity was discovered. He was discharged "on racial grounds", and went back to his previous employer to continue working as a surveyor until he was interned at Hay on December 8, 1941 (NAA: MP529/3, TRIBUNAL 4/46).

Suzuki fought tirelessly to prove his loyalties to the Australian government so that he could be released from internment. He submitted an application for release, and went before a tribunal on May 13, 1942. There he emphasised his desire to assist the war effort in any way he could, including being prepared to take the risk of being "taken prisoner... [or] shot as a traitor" (NAA: B883, NX32903). According to Oliver (2002), Suzuki and his sister, who had her own tribunal to contend with, saw themselves as Australians (282). Joseph even had a tattoo of a map of Australia (NAA: MP1103/2, NJ17051). He and his sister were supported by their community, who testified on their behalf. The Commanding Officer at Woolenook Wood Camp, where Suzuki was interned for some time, also aided his case, stating: "He is 100 percent Australian, hates the Japs and will not associate with them" (Nagata 1996, 106). Suzuki later explained in an interview for The Sunday Telegraph that he was "an Australian to the backbone" (Nagata 1996, 108).

Although the tribunal concluded in 1942 that Suzuki should be released, he remained interned until August 21, 1944 (NAA: D4028, SUZUKI JOSEPH). This was apparently due to reports from the Australian Military Forces (AMF) Eastern Command in July 1942 which argued that as a person with Japanese heritage born in Japan, Joseph was under "the influence of the fatalistic Emperor cult; [and] the obligation on Japanese to report intelligence to the Consulate," and that "evidence of conversion to Christianity was no argument for Australian orientation" (Oliver 2002, 285). The military was also concerned that his skills as a surveyor would be useful to the enemy (Nagata 1996, 107). Further, his Security Service assessment presented to the government argued that "the son of a Japanese is always regarded as a Japanese even if he had some other nationality" (Haid 2011, 168). Because of his prolonged internment, Suzuki suffered mentally and was hospitalised. This eventually led to his release (Haid 2011, 168). He and several of the other 'mixed race' or Australian-born internees did not get along with the Japanese nationals 
in the camp. They were referred to as 'The Gang' and were segregated in a separate tent (Nagata 1996, 107, 175). Suzuki himself said the other internees were friendly enough, but they had to "try to speak English" to communicate with him, as he did not speak any Japanese (NAA: MP529/3, TRIBUNAL 4/46). Suzuki's actions at Hay appear to have served as the inspiration for a fictional character named Peter Suzuki in After Darkness, an Australian novel based around Japanese internment at Loveday in South Australia (see Piper 2014, 63-65).

After his release, Suzuki returned to Newcastle, where he was naturalised on June 12, 1945 (NAA: A714, 29/11866). He also eventually changed his surname to his mother's maiden name due to continued discrimination. In Nagata's Unwanted Aliens (1996), Joseph's sister Hannah is recorded as stating that she did not wish for Joseph to be contacted for research, as it would upset him too much (235). No date of death has been located due to difficulty confirming his full legal name.

\section{DISCUSSION AND ANALYSIS}

Official treatment of Nikkei-Australians in the 1940s was heavily influenced by the White Australia Policy and the outbreak of World War II. The term 'Australian-born Japanese', appearing in official documentation from the time, indicates that Nikkei-Australians were not officially recognised as "real" Australians (Haid 2011, 128). Not only were they seen as foreign, but they faced further discrimination because they shared the same heritage as the enemy. Interestingly, this did not result in the three Nikkei-Australians above turning away from the country that rejected them, nor did it sway them from enlisting. Instead, they made the decision to fight for a country that imprisoned their families and distrusted them, even going so far as to falsify information or attempt to enlist multiple times, because they believed it was their duty and right as Australians-evidenced by Suzuki's assertion that he "was entitled to serve Australia" (Nagata 1996, 106). In doing this, they went against the stereotypes and assumptions held by the government and the greater Australian community, as exemplified by the White Australia Policy and Pearson's and Barnwell's racial theories, which popularised the idea that Nikkei could not assimilate.

The analysis that follows investigates the links between Nikkei-Australian identity and treatment of Nikkei-Australians by the Australian government and their local communities during World War II, looking at the schisms between three different images of Nikkei-Australians: how Nikkei were seen bureaucratically and legislatively, how they were seen by their local communities and peers, and how they saw themselves. This discussion will also draw on the experiences of the Japanese diaspora serving in the military in Canada and the United States, as well as Australian soldiers of non-Nikkei racial minority backgrounds, which have been more substantially documented and researched than those of their Australian counterparts. ${ }^{17}$ 
The three Nikkei-Australian soldiers chosen for this study enlisted at a time when Australian identity was often linked with race-particularly in legislation, where the Australian community was defined "in terms of colour" (Haid 2011, 61). However, those who identified as both Australian and Japanese, or who identified as Australian but looked outwardly Japanese, did not fit the stereotypes of 'foreignness' prevalent in Australian society at the time. These stereotypes served to conflate Nikkei-Australians with the soldiers in the Japanese military that Australia witnessed during wartime, who were regarded as "subhuman beast[s]" and "vermin" (Saunders 1994, 325-27). Moreover, they were thought of as being absolutely loyal to Japan (Oliver 2002, 275).

However, the experiences of these Nikkei-Australian soldiers during and before the war suggest that they considered themselves Australian, or at least outwardly identified as such. In particular, Japanese-born Joseph Suzuki appears to have identified strongly as Australian and distinctly not as Japanese. This is highlighted by his own reported assertion that he was "Australian to the backbone", and is reinforced by other indications such as his refusal to mingle with Japanese nationals during internment, and potentially also his Australia map tattoo (Nagata 1996, 105-8). His sister spoke of him as always being "a loyal Australian. The proof is that he got a medal from the Queen” (Nagata 1996, 235). Similarly, his mother testified that he had pro-Australian views (Oliver 2002, 285).

Statements made by Mario Takasuka also suggest that he felt stronger sympathies towards Australia, where he was born and raised, than to his familial ties to Japan. Takasuka is described by Sissons (1980) as "a man of strong patriotic sentiment" toward Australia, and evidence suggests this may be true (168). Of the Japanese influence on his upbringing, Takasuka had this to say:

My mother...brought us up on part Japanese food. Well, English-Japanese food, because she had to cook it on a wood stove and that sort of thing... We kids never learned to use chopsticks. We always used knives and forks... Father was a typical Japanese father... Both father and mother sang Japanese songs and they would make up verses and rhymes to celebrate something or designate something, or whatever. It seemed to be part of their upbringing... [Mother] played the Japanese instruments that we had there in those early days... I don't know what they were called.

(Lewis 2012, 31-32)

His words portray a typical country Australian upbringing with some Japanese cultural influence. His lack of knowledge regarding the Japanese music and songs of his parents seems to indicate a disinterest in and disconnect from his parents' culture, suggesting that he too may have identified more strongly with Australia than with his Japanese heritage. There are fewer primary sources relating to how Winston Ide self-identified, however the fact that he never made his heritage known to Japanese authorities during his time as a POW does suggest an allegiance to the Australian military. 
This corroborates the findings of research on North-American Nikkei which shows that Nikkei soldiers were often raised in multicultural environments, and identified with the country they were raised in. In the US, for example, many Nikkei-American soldiers saw themselves as American while still preserving their cultural and emotional ties to Japan (O 2011, 121-23, 204). Many put more weight on their non-Japanese heritage, outwardly appealing to be recognised as a part of their immediate local communities. Nikkei-Canadian soldiers, like their Australian and American counterparts, emphasised their love for Canada and their desire to be recognised as Canadians (Ito 1984, 164). Clark and Russell (1945) assert that Nikkei-American soldiers resented being set apart from other Americans and being called "Japs" or "Yank-Japs"; they preferred to simply be called "American" (701). ${ }^{18}$ This is a clear indication of their stronger associations with the country they were raised in, and a desire to be recognised as a part of that country without qualification.

Nikkei soldiers abroad saw enlistment as a way of proving their loyalty to, and achieving equality as citizens of, the countries where they were raised. Roy Ito's We Went To War (1984) asserts that in Canada, the Japanese diaspora joined the military to fight for the rights of Nikkei-Canadians, prove that they were loyal and thereby fight against governmental discrimination (8). ${ }^{19}$ Likewise, many Nikkei-Americans enlisted in military service to prove that they were good Americans and "basically no different in attitude or loyalty from American citizens whose forebears came from other lands" (Clark and Russell 1945, 698). Ken Ishii (2008), a Nikkei-British man who was drafted into the Japanese army, affirms this, stating, "In war you were forced to choose where your loyalties lay" (22).

Another common reason for enlistment was related to internment. In the US, some Nikkei-American internees were given the choice to serve in the military rather than continue their internment, providing an opportunity for freedom or variety in life that was denied while they were interned (Maranzani 2011). Some internees enlisted because they believed that their similarly interned families would be treated more favourably, or be given a better chance of release $(\mathrm{O}$ 2011, 210). In Australia, other non-European soldiers had similar reasons for enlistment. For many Indigenous Australians, the military was the first environment where they experienced equal treatment, as they were entitled to the same wages as non-indigenous soldiers. According to John Moremon from the Australian Department of Veterans' Affairs, they felt a sense of equality in serving, and joined in the hope that their service would help to advance equality and improve the chances of Indigenous Australians achieving citizenship during peacetime (Moremon n.d.). Others joined out of fear of being ostracised for "staying behind", or because they "believed the war was just; others sought adventure, good pay, or joined up because mates did", just as many European-Australians decided to do (Moremon n.d.). 
Did these reasons apply to the three individuals chosen for this paper? It is impossible to say. However, early releases from internment were granted by the Australian government to some Nikkei-Australian internees, and an examination of these early release cases presented in Nagata's (1996) research shows that the Australian army did give special consideration to internees whose family members had enlisted. This included Winston Ide's father Henry, who was released from Hay in 1942 (Nagata 1996, 103-8). Based on this, we can tentatively conclude that for some, the possibility of family members' release from internment may have been a factor behind the decision to enlist. Joseph Suzuki's statement that he was "entitled" to serve may imply that he also desired equal recognition (Nagata 1996, 106). This, along with other previously stated gestures, suggests that like their North American and non-European Australian counterparts, Nikkei-Australians who enlisted may have done so as one way to fight for recognition, with entrance into the military a clear sign of being accepted as insiders in the community (Ito 1984).

\section{Nikkei-Australians and the State during World War II}

Born and raised at the height of the White Australia Policy's influence, the Nikkei-Australian soldiers chosen for this research were, as discussed above, greatly impacted by race-based legislation and ideas surrounding nationality. During the period the policy was in force, race was officially linked to the idea of Australian nationality, and the two ideas were often conflated (Haid 2011, 240-41). At the time, mixed births were generally perceived by the greater Australian public as impure at best, as "one drop" of foreign blood was considered enough to taint the purity of the White Australian ideal (Yazdiha 2010, 32). Thus, people were racially divided from both social and legal perspectives into those who were of pure European descent and those who were not. This is exemplified by the Defence Act 1909's exclusion of nonEuropean Australians from military enlistment discussed earlier. Ethnicity, as "the application of systematic distinctions between outsiders and insiders" created an 'us and them' mentality that was compounded by the war against Japan and had roots in fear and animosity towards the other (Eriksen 2010, 22). Acceptance of Nikkei-Australians in formal contexts and through official channels was determined on a case-by-case basis, complicated by inconsistent or selective treatment of race in legislation at the time. While in theory all Nikkei-Australians were excluded from military service as a result of their enemy alien heritage, in practice several variables came into play. As will be shown below, Nikkei-Australians were generally branded with one nationality or the other depending on several factors, including how recognisable their Japanese heritage was in terms of name, physical appearance, birthplace and patrilineage. How they personally identified appears to have had little bearing on their treatment officially, although it may have influenced their treatment within the local community.

In general, the government used patrilineage as the basis for identification of heritage. As can be seen in the laws on citizenship, the nationality of the father was considered more influential than that of the mother. Mario Takasuka, Joseph Suzuki and Winston Ide all had Japanese fathers, and thus could all mo 
be classified as aliens under the Aliens Registration Act. These laws linked children to their fathers' nationality and ethnicity. The proceedings of Joseph Suzuki's internment appeal provide an example of how this law was applied in practice. Character witnesses for Suzuki were mainly questioned about the influence of his Japanese step-father, Sakuhei Suzuki. This demonstrates that the government believed the father figure to be a dominant role model, despite the fact that the two were biologically unrelated in this case, and that Suzuki had been in the care of his Anglo-Australian mother as a child. In contrast with the rest of the Suzuki family, Sakuhei was vehemently anti-British and had allegedly threatened to shoot the family if Joseph enlisted in the Australian military (Oliver 2002; Nagata 1996, 104). The witnesses, however, testified that the Suzukis were brought up by their mother "the Australian way", and argued against any influence from their step-father's pro-Japanese views (Oliver 2002, 284-85). Similarly, the AMF Eastern Command argued that the Ide family had an "Australian outlook", and thus could not have been influenced by their father even if he had had pro-Japanese views (Oliver 2002, 281). The strong influence of Ide's mother was highlighted in his appeal and likely influenced the Australian military's decision to allow Winston and his brother to continue their service without internment.

Physical appearance also influenced how Nikkei-Australians were identified and treated by the authorities. The Defence Act 1909 included the vague wording "sufficiently European" (Nagata 1996, 105), creating a loophole that allowed some mixed-race individuals to enter the military. Ide, who had mostly Caucasian features, appears to have not been identified as Nikkei by either Australian or Japanese officials at the time of his enlistment. Those with more Japanese features, such as Takasuka, had more documented difficulty enlisting than Ide. This seems to suggest that physical appearance, rather than genetic makeup, is how the military determined 'European-ness'.

Names were another point of difference to which Nikkei-Australians experienced reactions of varying intensity. Documents about the Ide family sometimes show 'Ide' spelt as the English surname "Eady", which suggests either that it was not immediately recognised as a common Japanese name at the time, or perhaps that the Ide family may have consciously adopted an Anglicised spelling for convenience. Whatever the case, the dual spellings were picked up by officials, with intelligence correspondence revealing an urgent request for more information on Ide's brother Roy, as "the English name of Eady might be misleading" (NAA: C123, 18502). Other Nikkei-Australians experienced significant difficulties as a result of their Japanese surnames. For example, Nikkei-Australian Moto Kozo Hasegawa, whose brother was a Nikkei-Australian soldier, "had had enough of being called a 'Jap' and decided that the easiest thing for him and his family was to adopt his ...mother's maiden name, Cole", as "WW2 was a difficult time, [and] the name Hasegawa along with Asian looks brought the worst out in some people but not all" (Hasegawa 2014). Joseph Suzuki also changed his name after the war, stating that "my present surname causes considerable embarrassment both to myself and my employers" (Nagata 1996, 108). ${ }^{20}$ Thus, names were one indication of Japanese heritage that the military used to identify enemy aliens, 
and the stigma attached to Japanese names appears to have carried over into the greater community and lingered following the end of the war.

Birthplace was another important factor, as it affected visa status and perceptions of national loyalty among officials. Suzuki is the only known Nikkei soldier to have been born in Japan, and was treated differently as a result (NAA: D4028, JOSEPH SUZUKI). He would have been a British citizen had he been born three months later, after his family had migrated, but the timing of his birth proved to be a determining factor in his treatment as an adult, and the chairman at his tribunal stated as much (Oliver 2002, 285; NAA: MP529/3, TRIBUNAL 4/46). Suzuki's discharge from the army and subsequent internment was at odds with the treatment of the other Nikkei-Australian soldiers profiled in this paper, suggesting that his birthplace influenced these outcomes. This is corroborated by the fact that Mario Takasuka's older Japanese-born brother Sho was unable to enlist in the military, and indicates that place of birth was considered more important than heritage in determining nationality and loyalty.

Despite their histories of military service, Nikkei-Australian soldiers experienced discrimination both during and after World War II. This is most evident in the lengths that some went to in order to hide their heritage or avoid prejudice, including changing their names. Suzuki's own anti-Japanese sentiment, evident in earlier quotes regarding his time in internment, may also have led to a desire to distance himself from his Japanese heritage in this way. Indigenous, Chinese and other non-European Australian veteran soldiers faced similar battles. Indigenous Australians were seen as disloyal and "contaminated by Japanese propaganda", and thus were perceived as potential collaborators with the Japanese and untrustworthy as allies (Saunders 1994, 326-29). Although many Indigenous Australians enlisted in the hope of effecting change to their citizenship rights, they received negligible recognition for their war efforts, and racism continued to permeate Australian society (Moremon n.d.). Furthermore, they were denied citizenship rights by the government until 1967, over two decades after the war ended. Chinese-Australian soldier Jack Goon reflects on a similarly mixed experience: "You got a lot of this 'Ching-Chong Chinaman' business, but it didn't worry me. Wearing uniform gave you a lot of confidence and a lot of pride" (Hui 2002; see also Moremon n.d.).

In the US, Nikkei-American soldiers were heralded as heroes after the war, which helped to sway public opinion on Americans of Japanese descent. As Clark and Russell (1945) state, "their achievements do more than volumes of propaganda could to demonstrate that democracy is stronger than race" (698). Despite this, Nikkei-American soldiers were treated poorly by some members of the public-including being refused service or denied work (Clark and Russell 1945, 703). While their war efforts helped to gradually shift perceptions and win over the public, it is clear that Nikkei-Americans and non-European Australians, including Nikkei-Australians, still faced discrimination from their respective governments and national communities following the war. 
While the White Australia Policy and wartime propaganda encouraged anti-Japanese sentiment, it did not appear to have a strong influence on the relationships between Nikkei-Australians and their local communities at an individual level. Many accounts suggest that the Nikkei-Australian population had integrated well into Australian communities (Oliver 2007). Due to the tightening of immigration restrictions post-1901, the majority of Nikkei-Australian families had been living in Australia for four decades by the time World War II broke out. They were therefore likely to have been well established in their respective local communities and would not have been a new or alien presence. This may have contributed to the fact that, while discrimination and racism certainly existed (especially on a policy level), local community attitudes were far more diverse. ${ }^{21}$ As explored below, the relationships between Takasuka, Ide and Suzuki and their local communities indicate that white Australians valued Japanese immigrants as good citizens with similar family values and work ethics. It was the Australians who did not have contact with Nikkei-Australians who continued to fuel anti-Japanese sentiment and encourage the official stance that Nikkei-Australians were Japanese, and not Australian (Haid 2011, 222).

During the war, the 'alien' identity ascribed to Nikkei-Australians bureaucratically was at odds with their acceptance by the immediate community (Haid 2011, 36). This schism is shown by the support that NikkeiAustralian internees received from their local communities. For example, Joseph Suzuki and his family were granted release from internment based on statements from community figures who willingly attested to their good character. The Mayor of Geelong testified that Suzuki's half-Japanese grandfather, also interned, was a "well-known, trusted and leading citizen" (Oliver 2002, 284). This and other testimonies were substantial enough to have an impact on Suzuki's release, with the chairman of his tribunal stating that "he has kept very good company and gives very good references" (NAA: MP529/3, TRIBUNAL 4/46). Similarly, Mario Takasuka and his family also received endorsements from people close to them. A statement from his commanding officer attested to the trust he had built with his military colleagues, while at his brother Sho's tribunal, the family reputation was described by neighbours as "absolutely one of the best" (NAA: MP529/3, TRIBUNAL 4/110). The Swan Hill police force felt ashamed and embarrassed at the prospect of arresting the Takasuka family, who were a part of the community, and sought advice from the attorney-general about circumventing the regulations (Oliver 2008, 137-39). The Takasuka family's strong reputation helped to keep not only Mario but also his mother Ichiko and sister Aiko Watters (née Takasuka) out of internment (Nagata 1996, 57). The early release of Winston Ide's father Henry from internment in October 1942 was also influenced by his presence in the community, along with his son's military service. After his release, security service officers reported "positive views of neighbours who respected Ide and welcomed his return" (Oliver 2002, 282). These examples of early release corroborate Oliver's research on the support of Nikkei-Australians by white Australian communities. Local support, 
according to Oliver, was "important in weighing whether a person's release would cause unrest in the community" (Oliver 2002, 284). Although racism in local communities did exist, these examples demonstrate that people who knew Nikkei-Australians showed support for those individuals' freedom at a time when the government declared them enemy aliens.

In general, the treatment of Nikkei-Australian soldiers varied noticeably, case by case. These variations were largely based on coincidental opportunities, circumstances of birth, physical appearance and family background. Takasuka, who had two Japanese parents, and Japanese-born Suzuki had more documented difficulties with regulations and discrimination than did Ide, ostensibly due to their different parentage, birth places and more distinct Japanese features. However, all three families were accepted by their local communities, indicating that their family backgrounds and physical appearance had little bearing on the support they received from their peers. While Nikkei-Australians diverged from the white Australian ideal of racial homogeneity (Collins 2012, 117), the words and actions of the soldiers discussed in this section suggest that they identified as Australians, even if the legal status of their nationality was vague. This also aligns with the documented experiences of North-American Nikkei soldiers and other non-European Australian soldiers during World War II. Despite the prevalence of racism within the government and greater Australian community towards Japanese immigrants and their descendants during World War II, evidence shows that Nikkei-Australians did assimilate, and that their local communities accepted them (Oliver 2002, 276).

\section{CONCLUSION}

This study has explored the stories of three Nikkei-Australian soldiers and their wartime experiences. While these experiences were all distinct and varied, we can draw several conclusions based on their similarities and differences. Firstly, the treatment of Nikkei-Australian soldiers by military and government officials significantly differed from how they were treated by their own communities and peers. While government rhetoric sought to position the Nikkei population as outsiders who were separate from, and a threat to, Australian society, the examples explored in this paper provide evidence that Nikkei-Australians were accepted by their communities and were respected and valued members of society. Furthermore, attitudes within local communities were much more varied than the bipartisan support of the political establishment for immigration restriction. Legislatively, the three Nikkei-Australians at the centre of this study were ambiguously positioned at best and enemy aliens at worst. Nonetheless, socially they displayed evidence of identifying as Australian and were accepted as such within their local communities.

While the scope of this study is limited in focus to the archival documents of three individuals, there is potential for further research. Seventeen NikkeiAustralians soldiers have been identified to date, but there may be more. 
In bringing to light the important stories of Nikkei-Australian community members who served in the armed forces and highlighting how their experiences differed from those of white Australians both legally and socially, we can delve into attitudes towards Australian identity and perceptions of Japan during World War II. Even while anti-immigration and anti-Japanese policies were in force and race-based conceptions of national identity were prevalent, the lives of the three soldiers examined in this study provide evidence that Nikkei-Australians were accepted as compatriots by their peers. With the recent increased interest in non-white Australian military history, the author hopes that this paper will bring to light these little-known NikkeiAustralian stories. These stories are important for recognition of the individual contributions of non-white Australian soldiers during World War II. Further, they highlight that, even during the era of the White Australia Policy, nonwhite immigrants not only lived in Australia but also identified strongly as Australian and integrated successfully into their communities.

\section{GLOSSARY}

\section{AIF}

Australian Imperial Force. This was the main force of the Australian military, and was made up exclusively of volunteers. The First AIF served in World War I and the Second AIF served in World War II.

AMF

Australian Military Forces

AWM

Australian War Memorial

Issei (一世)

First-generation Japanese-born immigrants

Nikkei (日系)

Members of the Japanese diaspora and their descendants

Nikkei-Australians

Japanese migrants to Australia and their Australian-born descendants

Nisei (二世)

Members of the second generation of the Japanese diaspora, born outside of Japan to Japanese (Issei) parents

POW

Prisoner of war

NAA

National Archives of Australia, accessible online at http://naa.gov.au/ 
APPENDIX: LIST OF KNOWN NIKKEI WHO SERVED IN THE AUSTRALIAN MILITARY IN WORLD WAR II

\begin{tabular}{|c|c|c|c|c|c|c|}
\hline & $\begin{array}{l}\text { Name } \\
\text { (Ordered } \\
\text { alphabetically } \\
\text { by family } \\
\text { namel }\end{array}$ & $\begin{array}{l}\text { Birthplace } \\
\text { and Date of } \\
\text { Birth (DOB) }\end{array}$ & $\begin{array}{l}\text { Enlistment } \\
\text { Location }\end{array}$ & $\begin{array}{l}\text { Military } \\
\text { Division } \\
\text { and } \\
\text { Service } \\
\text { Number }\end{array}$ & $\begin{array}{l}\text { Japanese } \\
\text { Heritage }\end{array}$ & Reference \\
\hline 1 & $\begin{array}{l}\text { Son of Okin and } \\
\text { Siam Ahmat } \\
\text { (name } \\
\text { unknown) }^{+}\end{array}$ & $\begin{array}{l}\text { Cossack, WA } \\
\text { or Onslow, } \\
\text { WA } \\
\text { (DOB } \\
\text { unknown) }\end{array}$ & Unknown & Unknown & $\begin{array}{l}\text { Japanese } \\
\text { mother, } \\
\text { Thai father }\end{array}$ & $\begin{array}{l}\text { Nagata } \\
1996,58\end{array}$ \\
\hline 2 & $\begin{array}{l}\text { George Mason } \\
\text { Furuya }\end{array}$ & $\begin{array}{l}\text { Prahran, VIC } \\
\text { Dec 26, } 1904\end{array}$ & $\begin{array}{l}\text { Caulfield, } \\
\text { VIC }\end{array}$ & $V \times 27226$ & $\begin{array}{l}\text { Japanese } \\
\text { father }\end{array}$ & $\begin{array}{l}\text { NAA: } \\
\text { B883, } \\
\text { VX27226 }\end{array}$ \\
\hline 3 & Leo Hasegawa & $\begin{array}{l}\text { (Birthplace } \\
\text { unknown) } \\
\text { Dec 21, } 1905\end{array}$ & $\begin{array}{l}\text { Geelong, } \\
\text { VIC }\end{array}$ & CMF & $\begin{array}{l}\text { Japanese } \\
\text { father }\end{array}$ & $\begin{array}{l}\text { NAA: } \\
\text { CT190/19, } \\
\text { 10/49 }\end{array}$ \\
\hline 4 & Harry Ide & $\begin{array}{l}\text { Sydney, NSW } \\
\text { Jan 17, } 1902\end{array}$ & $\begin{array}{l}\text { Paddington, } \\
\text { NSW }\end{array}$ & $\begin{array}{l}\text { AlF } \\
\text { NX66702 }\end{array}$ & $\begin{array}{l}\text { Japanese } \\
\text { father }\end{array}$ & $\begin{array}{l}\text { NAA: } \\
\text { B883, } \\
\text { NX66702 }\end{array}$ \\
\hline 5 & Winston Ide* & $\begin{array}{l}\text { Sydney, NSW } \\
\text { Sep 17, } 1914\end{array}$ & $\begin{array}{l}\text { North } \\
\text { Sydney, } \\
\text { NSW }\end{array}$ & $\begin{array}{l}\text { AlF } \\
\text { QX13648 }\end{array}$ & $\begin{array}{l}\text { Japanese } \\
\text { father }\end{array}$ & $\begin{array}{l}\text { NAA: } \\
\text { B883, } \\
\text { QX13648 }\end{array}$ \\
\hline 6 & Francis Ito & $\begin{array}{l}\text { Geelong, VIC } \\
\text { Jan } 28,1917\end{array}$ & $\begin{array}{l}\text { Geelong, } \\
\text { VIC }\end{array}$ & V167421 & $\begin{array}{l}\text { Japanese } \\
\text { father }\end{array}$ & $\begin{array}{l}\text { NAA: } \\
\text { B884, } \\
\text { V167421 }\end{array}$ \\
\hline 7 & $\begin{array}{l}\text { Selby Sakechi } \\
\text { Okamura }\end{array}$ & $\begin{array}{l}\text { Brisbane, } \\
\text { QLD } \\
\text { Jan 10, } 1911\end{array}$ & $\begin{array}{l}\text { Brisbane, } \\
\text { QLD }\end{array}$ & $\begin{array}{l}\text { AlF } \\
\text { QX35217 }\end{array}$ & $\begin{array}{l}\text { Japanese } \\
\text { father }\end{array}$ & $\begin{array}{l}\text { NAA: } \\
\text { B883, } \\
\text { QX35217 }\end{array}$ \\
\hline 8 & $\begin{array}{l}\text { Kazu (Kaz) } \\
\text { Milton Omaye }\end{array}$ & $\begin{array}{l}\text { Parramatta, } \\
\text { NSW } \\
\text { Nov 24, } 1923\end{array}$ & $\begin{array}{l}\text { Strawberry, } \\
\text { WA }\end{array}$ & NX139932 & $\begin{array}{l}\text { Japanese } \\
\text { father }\end{array}$ & $\begin{array}{l}\text { NAA: } \\
\text { B883, } \\
\text { NX139932 }\end{array}$ \\
\hline
\end{tabular}

\section{Notes}

* Case study examined in this paper.

† It is possible that this soldier is Patrick Ahmat, whose name is recorded in Nagata (1996). However, as I have been unable to corroborate this or find any military records to confirm whether the book refers to him or a brother, I have listed him this way. 
APPENDIX: LIST OF KNOWN NIKKEI WHO SERVED IN THE AUSTRALIAN MILITARY IN WORLD WAR II (CONTINUED)

\begin{tabular}{|c|c|c|c|c|c|c|}
\hline 9 & $\begin{array}{l}\text { Tomo (Tom) } \\
\text { Kevin Omaye }\end{array}$ & $\begin{array}{l}\text { Parramatta, } \\
\text { NSW } \\
\text { Feb 25, } 1925\end{array}$ & $\begin{array}{l}\text { Sydney, } \\
\text { NSW }\end{array}$ & NX178247 & $\begin{array}{l}\text { Japanese } \\
\text { father }\end{array}$ & $\begin{array}{l}\text { NAA: } \\
\text { B883, } \\
\text { NX178247 }\end{array}$ \\
\hline 10 & $\begin{array}{l}\text { Albert Joseph } \\
\text { Miller Dicinoski }\end{array}$ & $\begin{array}{l}\text { Brisbane, } \\
\text { QLD } \\
\text { Sep 21, } 1924\end{array}$ & $\begin{array}{l}\text { Redbank, } \\
\text { QLD }\end{array}$ & Q270458 & Unknown & $\begin{array}{l}\text { NAA: } \\
\text { B884, } \\
\text { Q270458 }\end{array}$ \\
\hline 11 & $\begin{array}{l}\text { Joseph } \\
\text { Dicinoski }\end{array}$ & $\begin{array}{l}\text { Glen Innes, } \\
\text { NSW } \\
\text { Feb 23, } 1904\end{array}$ & $\begin{array}{l}\text { Kelvin } \\
\text { Grove, QLD }\end{array}$ & Q265679 & $\begin{array}{l}\text { Japanese } \\
\text { grandfather }\end{array}$ & $\begin{array}{l}\text { NAA: } \\
\text { B884, } \\
\text { Q265679 }\end{array}$ \\
\hline 12 & $\begin{array}{l}\text { Ronald } \\
\text { Reginald } \\
\text { Dicinoski }\end{array}$ & $\begin{array}{l}\text { Charleville, } \\
\text { QLD } \\
\text { Dec 29, } 1924\end{array}$ & $\begin{array}{l}\text { Brisbane, } \\
\text { QLD }\end{array}$ & $\begin{array}{l}\text { RAAF } \\
\text { AC435239 }\end{array}$ & $\begin{array}{l}\text { Japanese } \\
\text { great- } \\
\text { grandfather }\end{array}$ & $\begin{array}{l}\text { NAA: } \\
\text { A9301, } \\
435239\end{array}$ \\
\hline 13 & $\begin{array}{l}\text { Zelda Winifred } \\
\text { Dicinoski }\end{array}$ & $\begin{array}{l}\text { Charleville, } \\
\text { QLD } \\
\text { Jan 9, } 1927\end{array}$ & $\begin{array}{l}\text { Brisbane, } \\
\text { QLD }\end{array}$ & $\begin{array}{l}\text { RAAF } \\
\text { W102610 }\end{array}$ & $\begin{array}{l}\text { Japanese } \\
\text { great- } \\
\text { grandfather }\end{array}$ & $\begin{array}{l}\text { NAA: } \\
\text { A9301, } \\
102610\end{array}$ \\
\hline 14 & $\begin{array}{l}\text { Ichero (Joseph) } \\
\text { Suzuki* }\end{array}$ & $\begin{array}{l}\text { Kobe, Japan } \\
\text { Feb 28, } 1922\end{array}$ & $\begin{array}{l}\text { Paddington, } \\
\text { NSW }\end{array}$ & $\begin{array}{l}\text { AlF } \\
\text { NX32903 }\end{array}$ & $\begin{array}{l}\text { Japanese } \\
\text { father }\end{array}$ & $\begin{array}{l}\text { NAA: } \\
\text { B883, } \\
\text { NX32903 }\end{array}$ \\
\hline 15 & $\begin{array}{l}\text { Mario } \\
\text { Takasuka* }\end{array}$ & $\begin{array}{l}\text { Swan Hill, } \\
\text { VIC } \\
\text { Nov 15, } 1910\end{array}$ & $\begin{array}{l}\text { Royal Park, } \\
\text { VIC }\end{array}$ & $\begin{array}{l}\text { AlF } \\
\text { VX37123 }\end{array}$ & $\begin{array}{l}\text { Japanese } \\
\text { mother and } \\
\text { father }\end{array}$ & $\begin{array}{l}\text { NAA: } \\
\text { B883, } \\
\text { VX37123 }\end{array}$ \\
\hline 16 & $\begin{array}{l}\text { Arthur } \\
\text { Yamaguchi }\end{array}$ & $\begin{array}{l}\text { Burketown, } \\
\text { QLD } \\
\text { Jan 11, } 1921\end{array}$ & $\begin{array}{l}\text { QLD lexact } \\
\text { location } \\
\text { unknown) }\end{array}$ & $\begin{array}{l}\text { North } \\
\text { Australia } \\
\text { Observer } \\
\text { Unit } \\
\text { Q230474 }\end{array}$ & $\begin{array}{l}\text { Japanese } \\
\text { father }\end{array}$ & $\begin{array}{l}\text { NAA: } \\
\text { B884, } \\
\text { Q230474; } \\
\text { Nagata } \\
1996,58 .\end{array}$ \\
\hline 17 & William Yoshida & $\begin{array}{l}\text { Brisbane } \\
\text { QLD } \\
\text { May 12, } 1917\end{array}$ & $\begin{array}{l}\text { Brisbane, } \\
\text { QLD }\end{array}$ & $\begin{array}{l}\text { CMF } \\
\text { Q28843 }\end{array}$ & $\begin{array}{l}\text { Japanese } \\
\text { father }\end{array}$ & $\begin{array}{l}\text { NAA: } \\
\text { B884, } \\
\text { Q28843 }\end{array}$ \\
\hline
\end{tabular}

Notes

$\ddagger$ Zelda Dicinoski is the only known female Nikkei-Australian to have joined the military during World War II. She served as a clerk/typist for the Australian and US Air Forces. 


\section{REFERENCES}

\section{Primary Sources}

The following sources can be found through the National Archives of Australia.

\section{Winston Ide}

NAA: A8231, 18/IDE WINSTON PHILLIP JAMES

NAA: B883, QX13648

NAA: C123, 18466

NAA: J1193, QX13648

Information about his family can be found in:

NAA ACT: A367/1, C69851 and A367/1, C69304

NAA VIC: MP529/3, 4/74

NAA: C123, 18467; MT1486/1; C123, IDE/HARRY; C123, 18458 and $\mathrm{C} 123,18502$

\section{Mario Takasuka}

NAA: B883, VX37123

Information about his family can be found in:

NAA ACT: A1/15, 25/27797 and A659, 1940/1/5346

NAA VIC: MP729/6, 65/501/147 and MP529/3, 4/110

\section{Joseph Suzuki}

NAA: D4028, SUZUKI JOSEPH

NAA: B883, NX32903

NAA: MP1103/1, NJ17051

NAA: MP1103/2, NJ17051

NAA: A714, 29/11866

NAA: MP529/3, TRIBUNAL 4/46

Information about his family can be found in:

NAA ACT: A367/1, C66204; A367/1, C18000/585 and A11797/1, WP8670

NAA VIC: MP508/1, 255/740/348; MP508/1, 255/742/572 and MP529/3 TRIBUNAL 4/163

NAA NSW: C123, 13681

\section{Secondary Sources}

2nd/3rd Australian Light Anti-Aircraft Regiment Association. 2011. Secretary's Report 1995: The Sentry's Log. Accessed 19 September, 2015. http://www. antiaircraft.org.au/about-us/secretarys-reports/secretarys-report-1995/.

Anderson, B. 2006. Imagined Communities: Reflections on the Origin and Spread of Nationalism. New York: Verso. 
AWM (Australian War Memorial). 2013. The Last Post Ceremony Commemorating the Service of (QX13648) Bombardier Winston Phillip James Ide, 2/10th Field Regiment RAA, Second World War [transcript]. Australian Capital Territory, Australia. Accessed 15 August, 2015. https://www.awm.gov.au/ collection/C1425433/.

.n.d.[a]. Roll of Honour: Winston Phillip James Ide. Accessed 15 August, 2015. https://www.awm.gov.au/people/rolls/R1687787/?query=\&section\%5B 0\%5D=people\&op=Search\&filter\%5Brcdb_id\%5D=528082/.

. n.d.[b]. Australian Prisoners of War: Second World War-Prisoners of the Japanese, Burma-Thailand Railway. Accessed 20 March, 2018. https://www. awm.gov.au/research/guide/pow-ww2-burma-thai/.

Baker, J., Hart, P. and Travers, R. 2017. In "A Chinese Australian Soldier at Gallipoli." Interview by Michael Cathcart [audio, 14:05-18:27]. Books and Arts, RN, 25 April. Accessed 18 August, 2017. http://www.abc.net. au/radionational/programs/booksandarts/a-chinese-australian-soldier-atgallipoli/8442714/.

Beaumont, J., I. Martinuzzi O’Brien and M. Trinca. 2008. Under Suspicion: Citizenship and Internment in Australia During the Second World War. Canberra, Australia: National Museum of Australia Press.

Blackburn, K. 2012. Sportsmen of Changi. Sydney: NewSouth Publishing.

Bryant, R. 1989. "Sergeant Takasuka," Take Post! Newsletter of the 2nd/3rd Australian Light Anti-Aircraft Regiment Association, vol. 6. Accessed 15 August, 2015. https://www.antiaircraft.org.au/take-post/take-post-archive?download $=10$ :take-post-1997/.

Bullard, S. 2006. "Representation of Japanese in Australian Military History and the Effect on Commemoration.' Symposium II: Remembering the Pacific War and Japan-Australia Relations." Ōsutoraria Kenkyu [オーストラリア研 究] 19: 18-23.

Clark, B. and Russell, O. 1945. "Japanese-American Soldiers Make Good," The American Mercury, no. 6 (June), 698-705.

Clyne, J., Smith, R., and Hodges, I. 2015. Chinese Anzacs. Canberra: Department of Veterans' Affairs.

Collins, K. 2012. "Imagining the Golden Race." In Australia's Asia: From Yellow Peril to Asian Century, edited by D. Walker and A. Sobocinska, 99-120. Crawley: UWA Publishing.

Densho. 2017. "Richard Sakakida," Densho Encyclopedia. Accessed 1 October, 2017. http://encyclopedia.densho.org/Richard_Sakakida/.

Eriksen, T. H. 2010. Ethnicity and Nationalism: Anthropological Perspectives. Volume 3. New York and London: Pluto Press. 
Fujita, F. 1993. Foo, A Japanese-American Prisoner of the Rising Sun: The Secret Prison Diary of Frank "Foo" Fujita. Denton: University of North Texas Press.

Growden, G. 2012. "Read It and Weep: Real Heroes Found on the Shelves, Not on the Field," The Sydney Morning Herald, 5 March. Accessed 24 August, 2015. http://newsstore.fairfax.com.au/apps/viewDocument.ac;jsessionid=87B1A5 525D78BB6105C71957BABBC13C?sy=afr\&pb=all_ffx\&dt=selectRange\&dr $=1$ month $\& s o=$ relevance $\& s f=$ text $\& s f=$ headline $\& \mathrm{rc}=10 \& \mathrm{rm}=200 \& \mathrm{sp}=$ brs $\& \mathrm{cl}$ $s=15 \&$ clsPage $=1 \&$ docID $=$ SMH120305JP5CPOI3KB6 $/$.

Haid, P. 2011. Reformulating Citizenship: The Nikkei in Canada and Australia. PhD thesis, School of History and Philosophy, University of New South Wales.

Hasegawa, A. 2014. "Story of Hasegawa Family," Nikkei Australia. Accessed 24 August, 2015. http://www.nikkeiaustralia.com/story-hasegawa-family/.

Hayman, R. 1980. Episodes: A Glimpse of Australia-Japan Relations 1859-1979. Canberra: Union Offset Co.

Hui, J. 2002. "Chinese-Australian Servicemen to be Honoured," The Sydney Morning Herald, 25 April. Accessed 18 August, 2017. https://www.smh.com. au/articles/2002/04/24/1019441262394.html.

Ishii, K. 2008. Caught Between Cultures. Australia: Platypus Graphics.

Ito, R. 1984. We Went to War. Canada: Canada's Wings.

Kaniya, T. [蟹谷 勉]. 1993. Shi ni itaru nōsaido [死に至るノーサイド]. Gushikawa, Japan: Asahi Bungei Bunko [朝日文芸文庫].

Kembrey, M. 2015. “Tony Albert's 'Confronting' Tribute to Indigenous Diggers Unveiled in Sydney's Hyde Park". The Sydney Morning Herald, 31 March. Accessed 18 January, 2018. http://www.smh.com.au/entertainment/artand-design/tony-alberts-confronting-tribute-to-indigenous-diggersunveiled-in-sydneys-hyde-park-20150331-1mbuzo.html.

“Kimi wa nōsaido no fue wo kītaka [君はノーサイドの笛を聞いたか] trailer 3min.” 2009. YouTube video, 3:18, posted by "Roundohmac," 8 September. Accessed 28 August, 2015. https://www.youtube.com/watch?v=9_mrRqVm404/.

Lane, D. 2011. "Hero's 'Enemy' Connections," The Sydney Morning Herald, 24 April. Accessed 24 August, 2015. http://www.smh.com.au/rugby-union/unionnews/heros-enemy-connections-20110423-1ds3s.html.

Lewis, G. 2012. The Growers' Paddy: Land, Water, and Co-Operation in the Australian Rice Industry to the 1990s. Sydney: The University of Sydney Co-Operatives Research Group.

Londey, P. 2015. "Indigenous Australian Servicemen," Australian War Memorial. Accessed 24 August, 2015. https://www.awm.gov.au/encyclopedia/ aborigines/indigenous/. 
Maranzani, B. 2011. "Unlikely World War II Soldiers Awarded Nation's Highest Honor," History Stories. Accessed 10 October, 2017. http://www.history.com/ news/unlikely-world-war-ii-soldiers-awarded-nations-highest-honor/.

Meaney, N. K. 2009. Australia and the World Crisis, 1914-1923. Sydney: Sydney University Press.

Moremon, J. n.d. "Indigenous Australians at War," Department of Veterans' Affairs. Accessed 20 September, 2017. https://www.dva.gov.au/i-am/aboriginalandor-torres-strait-islander/indigenous-australians-war/.

Nagata, Y. 1996. Unwanted Aliens: Japanese Internment in Australia. St Lucia: University of Queensland Press.

. 2001. "Certain Types of Aliens': The Japanese in Australia, 1941-1952." In Relationships: Japan and Australia, 1870s-1950s, edited by P. Jones and V. Mackie, 217-39. Parkville: University of Melbourne, Department of History.

2008. "Naive Patriotism: The Internment of Moshi Inagaki in Australia during the Second World War." In Under Suspicion: Citizenship and Internment in Australia during the Second World War, edited by J. Beaumont, I. Martinuzzi O'Brien and M. Trinca, 112-24. Canberra: National Museum of Australia Press.

Nagata, Y. and Nagatomo, J. 2007. Japanese Queenslanders: A History. St. Lucia: Bookpal for School of Languages and Comparative Cultural Studies, University of Queensland.

NAA (National Archives of Australia). 2017. Australia's Prime Ministers: John Curtin in Office. Accessed 26 April, 2017. http://primeministers.naa.gov.au/ primeministers/curtin/in-office.aspx.

O, Y. 2011. "Cultural Origins of the Kamikaze Special Attack Corps and the 442nd Regimental Combat Team During World War II: A Comparison Between the Japanese Soldiers Raised in Japan and the Nisei Soldiers Raised in America." PhD dissertation, Oklahoma State University. Accessed 26 April, 2017. https://shareok.org/handle/11244/6784/.

Oliver, P. 2002. "Who Is One of Us? (Re)discovering the Inside-Out of Australia's Japanese Immigrant Communities, 1901-1957." Japanese Studies 22 (3): 273-88.

. 2007. "Japanese Relationships in White Australia: The Sydney Experience to 1941." History Australia 4 (1): 5.1-5.20.

. 2008. "Citizens Without Certificates or Enemy Aliens? Japanese Residents Before 1947." In Under Suspicion: Citizenship and Internment in Australia during the Second World War, edited by J. Beaumont, I. Martinuzzi O'Brien and M. Trinca, 125-41. Canberra: National Museum of Australia Press.

Oliver, P. and NAA (National Archives of Australia). 2004. Allies, Enemies and Trading Partners: Records on Australia and the Japanese. Volume 20. Canberra: National Archives of Australia. https://doi.org/10.1080/10371390 22000036968/.

\section{T}

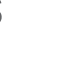


Pearson, C. H. 1893. National Life and Character: A Forecast. London: Macmillan and Co.

Piper, C. 2014. After Darkness. Sydney: Allen \& Unwin.

Queensland Government. 2014. Allied Translator and Interpreter Section (ATIS); Australian 1st Battalion; POW Compound and Interrogation Centre. Accessed 4 August, 2015. http://www.ww2places.qld.gov.au/places/?id=786/.

Rando, G. 2005. "Italo-Australians during the Second World War: Some Perceptions of Internment." Italian Studies in Southern Africa 18 (1): 20-51.

Rowland, M. 2017. "Fall of Singapore Anniversary: How a Military Defeat Changed Australia," ABC News, 14 February. http://abc.net.au/news/2017-02-14/fallof-singapore-75-year-anniversary-commemorated/8267650/.

San Francisco Maritime National Park Association. 2007. USS Pampanito (SS-383): The Third War Patrol. Accessed 22 August, 2015. http://maritime.org/ pamphist/patrol3.htm.

Saunders, K. 1994. "The Dark Shadow of White Australia: Racial Anxieties in Australia in World War II." Ethnic and Racial Studies 17 (2): 325-41. https:// doi.org/10.1080/01419870.1994.9993827/.

Sissons, D. C. S. 1956. Attitudes to Japan and Defence, 1890-1923. Masters thesis, Faculty of Arts, The University of Melbourne.

1980. "A Selector and His Family." Hemisphere 25 (3): 168-74.

. 1986. "Muramats, Jirō (1878-1943)." Australian Dictionary of Biography, National Centre of Biography, Australian National University. Accessed 6 May, 2018.http://adb.anu.edu.au/biography/muramats-jiro-7689/text13459/.

State Library of South Australia. 2017. "T 1917-2016”, Savill Index of The Advertiser Funeral Notices. Accessed 1 November, 2017. http://www.slsa.sa.gov.au/fh/ savill/savill-T.html.

Stead, A. 1904. "Japan and the Policy of a 'White Australia'" The Monthly Review 16: 84-104.

Yazdiha, H. 2010. "Conceptualizing Hybridity: Deconstructing Boundaries through the Hybrid." Formations 1 (1): 31-38.

Yu, O. 2017. “A Chinese Australian Soldier at Gallipoli." Interview by Kate Evans [audio, 18:27]. Books and Arts, RN, 25 April. Accessed 18 August, 2017. http://www.abc.net.au/radionational/programs/booksandarts/a-chineseaustralian-soldier-at-gallipoli/8442714/. 